\title{
PREALBUMINS IN THE VAGINAL FLUSHINGS OF THE MARMOSET, CALLITHRIX JACCHUS
}

\author{
J. P. HEARN AND MARILYN B. RENFREE* $\dagger$ \\ M.R.C. Unit of Reproductive Biology, 2 Forrest Road, Edinburgh, and \\ *Department of Animal Genetics, University of Edinburgh, Edinburgh
}

(Received 25th September 1974)

The marmosets (F. Gallithricidae), in common with other South American primates, do not menstruate. This is a major disadvantage in animals which otherwise have many attributes as experimental models for studies in reproductive physiology. The conventional methods of determining the stage of the ovarian cycle by means of vaginal smear cytology do not work for the common marmoset (Callithrix jacchus). The presence of spermatozoa in the vaginal smear is no indication of oestrus because marmosets mate frequently and apparently indiscriminately throughout the cycle and early pregnancy (Hearn \& Lunn, 1974). The patterns of LH, oestradiol and progesterone in the peripheral plasma of the common marmoset show that this species has a clearly defined ovarian cycle of $16.4 \pm 1.7$ days (Hearn \& Lunn, 1974), and it seemed possible that some change in the cervical or vaginal mucus might be used to monitor the ovarian cycle. We have examined samples of vaginal lavage for $\mathrm{pH}$, peroxidase activity (Linford, 1974), vaginal cytology and protein composition. Only the protein patterns showed any correlation with the hormonal cycle. These changes were restricted to the prealbumins, a group of small proteins which appear between the albumin band and the solvent front when separated by acrylamide gel electrophoresis.

Vaginal washings were taken daily from five females during seventeen ovarian cycles. The cervical and vaginal regions were flushed with $100 \mu \mathrm{l}$ sterile physiological saline, introduced into the vagina by a 21-gauge needle tipped with a 5-mm length of plastic tubing. A 1-ml Eppendorf pipette tip was first inserted into the vagina as a speculum and the needle with its plastic tip was inserted through this so that the flushings did not come in contact with the external genitalia. The vaginal flushings were analysed for proteins using acrylamide slab gel electrophoresis (Reid \& Bieleski, 1968) with the solutions used by Davis (1964). Aliquots $(50 \mu \mathrm{l})$ of the recovered flushings were added to $25 \mu \mathrm{l}$ bromophenol blue in $40 \%$ sucrose and applied to the gels. Aliquots of saline alone $(50 \mu \mathrm{l})$, marmoset plasma $(2.5 \mu \mathrm{l})$ and vaginal flushings $(50 \mu \mathrm{l})$ from pregnant marmosets were used as controls. Blood samples $(0.4 \mathrm{ml})$ were taken daily or every 2nd day and analysed for progesterone using the assay of Neal, Baker, McNatty \& Scaramuzzi (1975). All samples were assayed in duplicate and the limit of sensitivity was $1 \mathrm{ng}$ progesterone/ml plasma.

$\dagger$ Present address: School of Environmental and Life Sciences, Murdoch University, Western Australia. 


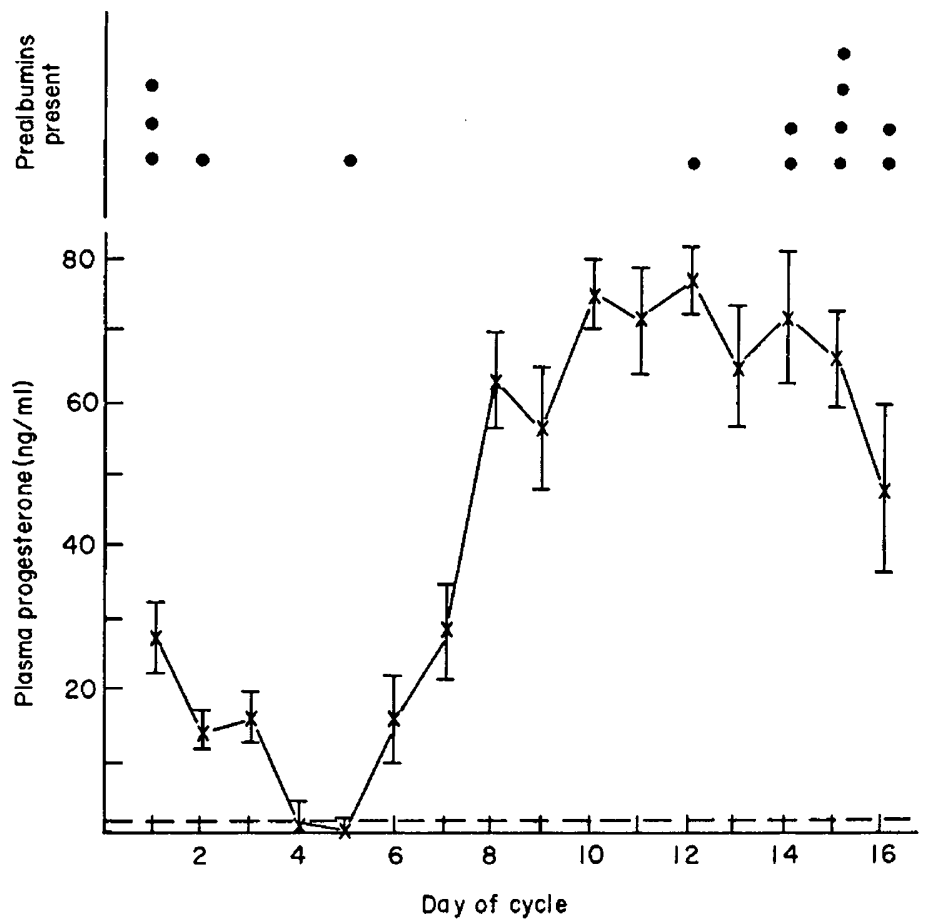

Text-FIG. 1. Graph to show the correlation between the presence of prealbumins in vaginal washings of common marmosets and the level of peripheral plasma progesterone (mean \pm S.E.M.) during the ovarian cycle. The horizontal broken line indicates the limit of sensitivity of the assay. The data represent seventeen cycles from five females. When prealbumins appeared on 2 consecutive days, only the day on which the greatest concentration was found is indicated.

In fourteen of the seventeen cycles sampled, prealbumins appeared in the vaginal flushings on 1 or on 2 consecutive days of the cycle. These proteins usually appeared during the late luteal phase when the plasma progesterone level was falling (Text-fig. 1). Prealbumins were not seen with the control tests of plasma, saline or vaginal lavage specimens from pregnant marmosets.

Prealbumins seem to be characteristic of reproductive tissues and have been described in the flushings, exudates and homogenates of the uterus in species such as the rabbit (Beier, 1970), human (Beier, Kühnel \& Petry, 1971), baboon (Peplow, Breed, Jones \& Eckstein, 1973), wallaby and opossum (Renfree, 1973, 1974), roe deer (Aitken, 1974) and mouse (R. J. Aitken, personal communication). In all these reports, the appearance of the prealbumins reflected the hormonal status of the animal, but no particular function has yet been demonstrated for these small protein molecules.

The cyclic appearance of prealbumins in the vaginal flushings of marmosets that we report here may offer a way of determining the stage of the ovarian cycle in this species.

\section{REFERENGES}

Artken, R. J. (1974) Delayed implantation in the roe deer (Gapreolus capreolus). Ph.D. thesis, University of Cambridge.

BeIER, H. M. (1970) Protein patterns of endometrial secretion in the rabbit. In Ovo-Implantation, Human 
Gonadotrophins and Prolactin, pp.157-163. Eds. P. O. Hubinont, F. Leroy, G. Robyn and P. Leleux. Karger, Basel.

Beier, H. M., Kühnel, W. \& Petry, G. (1971) Uterine secretion proteins as extrinsic factors in preimplantation development. Adv. Biosci. 6, 165-189.

Davis, B. J. (1964) Disc electrophoresis. II. Method and application to human serum proteins. Ann. N.Y. Acad. Sci. 121, 404-427.

Hearn, J. P. \& LunN, S. F. (1975) The reproductive biology of the marmoset monkey, Callithrix jacchus. In The Breeding of Simians and their Uses in Developmental Biology, Eds. F. T. Perkins and P. N. O'Donoghue. Laboratory Animal Handbook, Vol. 6 (in press).

LiNford, E. (1974) Gervical mucus: an agent or a barrier to conception. J. Reprod. Fert. 37, 239-250.

Neal, P., Baker, T. G., McNatty, K. P. \& Scaramuzzi, R. J. (1975) Influence of prostaglandins and HGG on progesterone concentration and oocyte maturation in mouse ovarian follicles maintained in organ culture. F. Endocr. 65 (in press).

Peplow, V., Breed, W. G., Jones, G. M. \& Eckstein, P. (1973) Studies on uterine flushings in the baboon. 1. Method of collection, cellular composition and protein electrophoretic profiles in animals with and without intrauterine contraceptive devices. Am. F. Obstet. Gynec. 116, 771-779.

REID, M. S. \& BreLEski, R. L. (1968) A simple apparatus for vertical flat-sheet polyacrylamide gel electrophoresis. Ann. Biochem. exp. Med. 22, 374-381.

Renfree, M. B. (1973) Proteins in the uterine secretions of the marsupial, Macropus eugenii. Devl Biol. $32,41-49$.

RENFREE, M. B. (1975) Uterine proteins during gestation in the marsupial, Didelphis marsupialis virginiana. J. Reprod. Fert. 42, 163-166. 